This item was submitted to Loughborough's Research Repository by the author.

Items in Figshare are protected by copyright, with all rights reserved, unless otherwise indicated.

\title{
Nanomaterials in construction - what is being used, and where?
}

PLEASE CITE THE PUBLISHED VERSION

http://dx.doi.org/10.1680/jcoma.16.00011

\section{PUBLISHER}

(C) Thomas Telford (ICE Publishing)

\section{VERSION}

VoR (Version of Record)

\section{PUBLISHER STATEMENT}

This work is made available according to the conditions of the Creative Commons Attribution-NonCommercialNoDerivatives 4.0 International (CC BY-NC-ND 4.0) licence. Full details of this licence are available at: https://creativecommons.org/licenses/by-nc-nd/4.0/

\section{LICENCE}

CC BY-NC-ND 4.0

\section{REPOSITORY RECORD}

Jones, Wendy, Alistair Gibb, Chris Goodier, Phil Bust, Mo Song, and Jie Jin. 2016. "Nanomaterials in Construction - What Is Being Used, and Where?". figshare. https://hdl.handle.net/2134/21419. 


\section{Nanomaterials in construction - what is being used, and where?}

Wendy Jones PhD, RN, SPCHN(OH), C.ErgHF

Researcher, School of Civil and Building Engineering, Loughborough University, Loughborough, UK (corresponding author: w.jones2@|boro.ac.uk)

Alistair Gibb PhD, CEng, MICE, MCIOB

$\mathrm{ECI}$ Royal Academy of Engineering Professor, School of Civil and Building Engineering, Loughborough University, Loughborough, UK

Chris Goodier PhD, MCIOB, FICT, FHEA

Senior Lecturer, School of Civil and Building Engineering,

Loughborough University, Loughborough, UK

\author{
Phil Bust PhD \\ Researcher, School of Civil and Building Engineering, Loughborough \\ University, Loughborough, UK \\ Mo Song PhD, MCSA, MCCS \\ Professor in Polymer Science and Nanotechnology, Department of \\ Materials, Loughborough University, Loughborough, UK \\ Jie Jin PhD \\ Researcher, Department of Materials, Loughborough University, \\ Loughborough, UK
}

Identifying where nanomaterials are present in construction materials is challenging. Academic literature reports what nanotechnology can offer construction, but this can differ from the reality of what is currently in use. Furthermore, it is difficult to source accurate information regarding nano-enabled products on the market; under current legislation, the declaration of nano content is voluntary and there is no requirement to provide details within safety data sheets. Although publically available information remains opaque and incomplete, several studies and reports have attempted to clarify this situation. This research builds on this information, presenting an overview of the nano-enabled products currently available for use in construction. This is based on the literature, manufacturers' published information and on discussions with suppliers and end users. Concrete, glass and coatings are the most widely available nano-enabled products, together with insulation and special steels. The precise nanomaterial used in each case however, and the form and quantity involved can be difficult to identify. This makes assessing the risks difficult, which is problematic, as some nanomaterials are considered to be hazardous. More detailed information regarding commercially available products will be important if risks are to be managed, enabling the industry to take full advantage of the benefits of nanotechnology.

\section{Introduction}

Nanoscale refers to dimensions in the range $1-100 \mathrm{~nm}$, with nanomaterials being those that contain particles (or sometimes spaces or pores) in this range in at least one plane. To appreciate how small nanoscale is, consider that a human hair is around $100000 \mathrm{~nm}$ thick $(0 \cdot 1 \mathrm{~mm})$. Figure 1 illustrates this in another way: the ratio between a carbon fullerene and a small grapefruit is about the same as the ratio between the grapefruit and the Earth.

Nanomaterials can be found in foods, textiles and cosmetics as well being used in the electronics, automotive and aeronautical industries (Keller et al., 2013). Nanotitanium and nanozinc are added to sun protection creams (Schilling et al., 2010); nanosilica is used as a filler and whitener in toothpastes; and nanosilver is added to socks and other consumer goods for its anti-microbial properties, as well as being used in medical and food hygiene applications (EC, 2012).

Nanomaterials are also being used increasingly in construction (AECOM, 2014; Teizer et al., 2009) and offer many useful and desirable properties. Their addition to concrete, for example, can improve compressive and tensile strength, and abrasion resistance. Associated with this is the (claimed) potential to reduce global cement consumption, with the associated energy and environmental benefits that this entails (Raki et al., 2010). Energy savings may also come from the use of very effective nano-enabled insulation materials; and nanomaterials could replace more toxic compounds in coatings (Pagliaro et al., 2009). The use of nanomaterials is predicted to rise substantially, accounting for $50 \%$ of building materials by the year 2026 (AECOM, 2014).

Although there is much published about nanotechnology and nanomaterials in construction (over 300 papers in Construction Materials alone in the last 10 years), it can be difficult to obtain a clear picture of exactly which materials have been used, where, and in what quantities. Not all materials that show promise have been, or will be, successfully converted into marketable products - there is, for example, a substantial difference (practically and financially) between laboratory research on small samples of cement paste and the realities of 


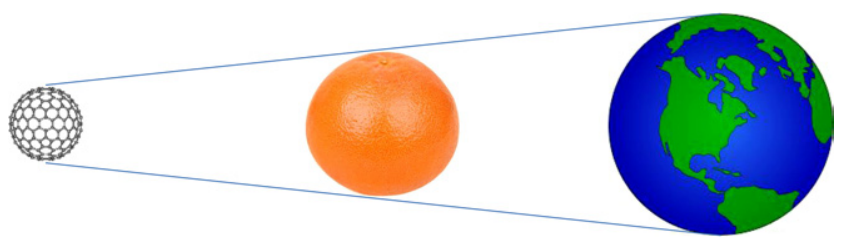

Figure 1. A carbon fullerene, a grapefruit and the Earth

producing commercially multiple tonne quantities of concrete. A review of the existing summary papers on the use of nanomaterials in construction (presented in Supplementary Information) found that many fail to differentiate clearly between materials that are still at an early stage of development (and may or may not progress to commercial viability) and those that are already available for use in the built environment. Further review of the academic literature, manufacturers' information, the popular press and interviews with those working in construction has confirmed that there are, in fact, many areas of uncertainty and misinformation in relation to nanomaterials, both in construction and more widely. This paper begins by considering why this might be so, highlighting some of the misunderstandings and areas of confusion around the use of nanomaterials. A summary of nanomaterials in the construction industry is then presented, with an emphasis on products that are commercially available rather than those that are believed to be at an earlier stage of development.

This research is part of a 3-year, multi-disciplinary project funded by the UK's Institution of Occupational Safety and Health to explore the application and management of nanomaterials in the construction and demolition sectors through academic and commercial literature and interviews with stakeholders. A second objective was to test samples of nanoenabled construction products and establish the likelihood of nanoparticle release when buildings are demolished and the materials recycled. The results of these tests, plus additional details relating to the potential health risks of nanomaterials are reported elsewhere (e.g. Jones et al., 2015a, 2015b) (other papers are in progress).

\section{Myths, misunderstandings and misconceptions}

\section{1 'Nanomaterials are clearly defined"}

Nanomaterial definitions vary widely (David et al., 2013) - a particular substance may be classed as a nanomaterial in one country but not in another. This is a contentious area. The EU has been debating its definition of nanomaterials for over 5 years, with a revised version due imminently (Rauscher and Roebben, 2015); and the USA does not have a formal definition at all. Variations between nanomaterial definitions include the following.

Most definitions consider nanoscale as being 1-100 nm, but may include larger dimensions as long as other criteria are met. Some nanotoxicologists consider the upper boundary unhelpful as toxicology does not change abruptly at the $100 \mathrm{~nm}$ cut-off point (Donaldson and Poland, 2013; Oberdörster et al., 2007; van Broekhuizen et al., 2012); a report by the International Agency for Research on Cancer (IARC, 2010) considers nanoscale titanium as being $1-150 \mathrm{~nm}$ in size; and materials with dimensions as low as $0 \cdot 1 \mathrm{~nm}$ are also technically nanoscale (Zhu et al., 2004).

- Some definitions, such as that of the EU (EC, 2011; ECJRC, 2014), only include materials that contain nanoparticles; others include nanostructured materials that have nanosized spaces or pores but no particles (e.g. BSI, 2011).

- Some definitions only include materials that are intentionally produced (often known as engineered nanomaterials or manufactured nanomaterials (MNMs); others include naturally occurring materials.

- There is also variation in how definitions consider particles that are aggregated or agglomerated (bound together), what proportion of particles must be nanoscale for the definition to apply, and whether particularly novel properties must be present for categorisation as a nanomaterial.

These differences make it difficult to frame and implement regulations and to interpret manufacturers' literature. They also create challenges when studying or writing academic papers, as different conceptualisations might be used in each case.

\section{2 "Nanomaterials are new"}

Some nanomaterials have indeed been created or discovered in recent years - examples include graphene, which is a layer of carbon an atom thick, isolated in 2004 (Novoselov et al., 2004), and carbon nanotubes (CNTs) (Iijima, 1991), essentially such a layer rolled into a tube. However, substances of nanoscale proportions have been around for much longer. Naturally occurring nanoparticles include some viruses and parts of the ash released by volcanos; naturally occurring nanostructures contribute to the colours of butterfly wings (Giraldo, 2008) and to leaf surfaces that are able to shed water easily (Greßler et al., 2010). Many coloured pigments used in paints and coatings are nanoscale, and have been so since the earliest cave paintings (Orfescu, 2014); steel-making has been based on nanotechnological methods for over 200 years (Kolpakov et al., 2007).

Although many novel nanomaterials are now being developed, the majority of nano-enabled products are still based on older 
substances. For example, rubber for tyres contains both carbon black and synthetic amorphous silica (SAS) with SAS also being used as a filler or flow agent in powders, foods and toothpaste. Together, these two materials account for $97 \%$ of the nanomaterial use in Europe (EC, 2012; IARC, 2010).

\section{3 'Nanomaterials are hazardous'}

One group of nanomaterials that has prompted concerns regarding toxicity is CNTs, with newspaper headlines such as 'The micro-particles that could pose the same risk as asbestos' (Derbyshire, 2008). CNTs, like asbestos, are fibre-shaped particles, with a high aspect ratio (i.e. their length is at least three times their width, and often many times more). They are therefore able to penetrate deep into the lungs, but are difficult for the normal protective mechanisms to clear (Donaldson et al., 2013), and one specific type of CNT has been identified as carcinogenic by the IARC (Grosse et al., 2014). However, CNTs exist in many different forms (perhaps in the order of 50000 different variants (WHO, 2012)) and they vary in their toxicity, with short or tangled forms appearing to be less toxic than those that are long and stiff (Donaldson et al., 2013). This could enable manufacturers to select nanomaterials that have safer dimensions (if they choose to, and provided this does not conflict with the required functionality). Other modifications such as small changes to the chemistry of CNTs, the use of coatings or different processing methods can also reduce their toxicity, so that CNTs can be designed that are intrinsically less hazardous (Al-Jamal et al., 2012; Costa, 2014).

The same variability exists for other nanomaterials. Nanomaterials have high surface area per unit of mass, making them more reactive and potentially contributing to increased toxicity (Oberdörster et al., 2007). However, the chemistry, shape, electrical charge, solubility and structure of materials will also influence their toxicity. For example, amorphous silica (the type typically used in nano-enabled construction materials) is much less toxic than crystalline silica, which, in its respirable, non-nano form, will be familiar to those working in construction as the cause of silicosis.

Due to the wide variability of nanomaterials, it is often difficult to compare the studies done to assess their toxicity, particularly as the majority of studies do not adequately describe the material used in terms of the characteristics mentioned above (size, shape, charge etc.) (Boverhof and David, 2010; Krug, 2014). It would be ideal if the nanomaterials tested in terms of their toxicity were identical to those used in products, but most testing is conducted with materials produced specifically for research purposes rather than on those taken from commercially available products. At this stage, therefore, it is only possible to state that some nanomaterials are hazardous, and that some are more hazardous than others.

\section{4 "Nanomaterials are easy to identify"}

There is no requirement under European or UK law for most nano-enabled products to be identified as such. Products labelled as 'nano' may contain nanoparticles, be nanostructured (i.e. they have nanoscale pores but no nanoparticles), be developed or manufactured using nanotechnology (but contain no nanomaterial) or use the name purely for marketing purposes (Jones et al., 2015b). Figure 2 shows a product that is marketed as a 'nano-coating' on wood surfaces, but does not actually contain nanoparticles.

Where products do contain nanomaterials and state this, many do not give information regarding the specific nanomaterials used or the quantity contained (Jones et al., 2015a). Safety data sheets in the UK and Europe are not required to specify the presence of nanomaterials, as they need only list substances that would be categorised as hazardous under the Classification, Labelling and Packaging (CLP, 2009) regulations. Figure 3 shows an extract from a safety data sheet for a coating product; CNTs are not listed in the ingredients, even though the product is marketed as a coating that '...combines CNT in an epoxypolyamide formulation'. Several authors have reported that safety data sheets rarely, if ever, contain details regarding nanomaterials (Larraza et al., 2015), and in fact they may actually contain incorrect data. For example, Lee et al. (2012) reported finding safety data sheets for CNTs that presented the published hazard data for graphite - a material that is chemically the same but very different in terms of structure and toxicity.

\section{5 'Nanoparticle exposure is predictable'}

Predicting nanoparticle release and the extent to which workers might be exposed is difficult, beyond the basic

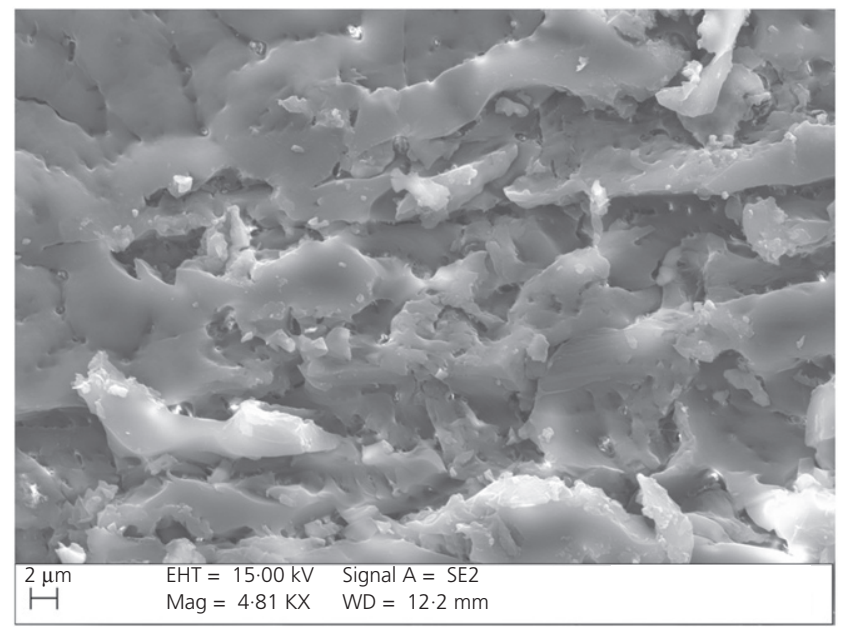

Figure 2. SEM image of a coating marketed as a 'nano-coating' but contains no nanoparticles 
3.2 Mixture:

\begin{tabular}{|l|c|c|l|l|l|}
\hline \multicolumn{1}{|c|}{ Chemical name } & \multicolumn{1}{|c|}{ CAS\# } & EINECS\# & \multicolumn{1}{|c|}{$\begin{array}{c}\text { EU classification } \\
\text { (67/548/EEC) }\end{array}$} & \multicolumn{1}{c|}{$\begin{array}{l}\text { CLP annex VI } \\
\text { classification }\end{array}$} & $\%$ \\
\hline Epoxy resin & $25068-38-6$ & $500-033-5$ & $\begin{array}{l}\text { Xi, N R36/38, R43, } \\
\text { R51/53 }\end{array}$ & $\begin{array}{l}\text { Skin Irrit. Cat 2 (H315), } \\
\text { Eye Irrit. Cat 2 (H319), } \\
\text { Skin Sens. Cat 1 (H317), } \\
\text { Aq. Chronic Cat 2 (H411) }\end{array}$ & $35-45$ \\
\hline Talc & $14807-96-6$ & $238-877-9$ & $\begin{array}{l}\text { No EU classification } \\
\text { or R phrase }\end{array}$ & No GHS Classification & $25-35$ \\
\hline Tert-Butyl acetate & $540-88-5$ & $208-760-7$ & F R11, R66 & $\begin{array}{l}\text { Flam. Liq. Cat 2 (H225) } \\
\text { EUH066 }\end{array}$ & $10-20$ \\
\hline
\end{tabular}

\begin{tabular}{|l|c|c|l|l|l|}
\hline Trimethylbenzene & 25551-13-7 & 247-099-9 & $\begin{array}{l}\text { Xi, Xn, R10, R21/22, } \\
\text { R36/38 }\end{array}$ & $\begin{array}{l}\text { Flam. Liq. Cat 2 (H226), } \\
\text { Acute Tox. Cat 4 (H302, } \\
\text { H312), Skin Irrit. Cat 2 } \\
\text { (H315), Eye Irrit. Cat 2 } \\
\text { (H319) }\end{array}$ & $<5$ \\
\hline 1,2,4-Trimethylbenzene & $95-63-6$ & $202-436-9$ & $\begin{array}{l}\text { Xi, Xn, N R10, R20, } \\
\text { R36/37/38, R51/53 }\end{array}$ & $\begin{array}{l}\text { Flam. Liq. Cat 3 (H226), } \\
\text { Acute Tox. Cat 4 (H332), } \\
\text { Skin Irrit. Cat 2 (H315), } \\
\text { Eye Irrit. Cat 2(H319), } \\
\text { STOT SE Cat 3 (H335), } \\
\text { Aq. Chronic Cat 2 (H411) }\end{array}$ & \\
\hline
\end{tabular}

Figure 3. Extract from a safety data sheet for a coating marketed as containing CNTs. The CNTs are not mentioned anywhere in the safety data sheet

principle that particle release from stable solid materials is negligible and that release from aerosols or powders is potentially much higher (Baron, 2015; Hansen et al., 2014). There are several reasons for this.

- There is a lack of certainty regarding which products might contain nanomaterials, as discussed earlier. In addition, nanomaterials may be released in a form different from that in which they were added - particles can be changed through chemical reactions or through agglomeration or aggregation.

- Weathering or machining of products may increase the potential for particle release, but there is some evidence (albeit incomplete and limited) that the nanomaterials released are often still bound to the underlying matrix rather than being free nanoscale particles (Froggett et al., 2014; West et al., 2016).

- Nanoparticles can be released from products that did not intentionally contain nanomaterials - thus the demolition of traditional concrete produces particles of many sizes, including the nanoscale (Azarmi et al., 2014, 2015).

In practice, therefore, the only way to assess nanoparticle exposure is to measure it, quantifying particle release from commercially available products in real-world scenarios.

\subsection{Released nanoparticles are easy to measure}

Accurate assessment of worker exposure (e.g. to dust or aerosols) is important, as it influences the 'dose' an individual is likely to receive, which in turn predicts toxicity. The principle that 'the dose makes the poison', attributed to Paracelsus writing in 1564 (Deichmann et al., 1986) is as true for nanomaterials as it is for other substances. Traditionally, dust or particle release is measured using mass-based methods, and recommended exposure limits are given in $\mathrm{mg} / \mathrm{m}^{3}$. Although these techniques can be used for nanomaterials, they are relatively insensitive (Donaldson and Poland, 2013; Kuhlbusch et al., 2011; Savolainen et al., 2010). Figure 4 shows how the presence of nanomaterials can have a relatively small impact on the mass of a dust sample, and thus may be missed or considered insignificant when using mass-based approaches. An alternative method is to count the number of particles, which is much more sensitive. However, the equipment required to do this is relatively new; it is generally too large to be easily portable and is particularly unsuited to taking measurements of individual workers' exposure (Methner et al., 2009a). In addition, it can be difficult to differentiate between the nanoparticles released by a particular process or activity and those in the background, for example, from things such as tobacco smoke (van Broekhuizen et al., 2011) or exhaust fumes (Kumar and Morawska, 2014). 


\begin{tabular}{lccc}
\hline $\begin{array}{l}\text { Number of micron-sized } \\
\text { particles }(1 \mu \text { m diameter, shown } \\
\text { as large dark dots }\end{array}$ & 100 & 100 & 100 \\
\hline $\begin{array}{l}\text { Number of nanoparticles (100 nm } \\
\text { diameter, shown as small } \\
\text { pale dots }\end{array}$ & 100 & 400 & 900 \\
\hline $\begin{array}{l}\text { Proportion of particles (by } \\
\text { number) that are nanoscale }\end{array}$ & $50 \%$ & $80 \%$ & $90 \%$ \\
\hline $\begin{array}{l}\text { Proportion of particles (by } \\
\text { volume (or mass, assuming } \\
\text { equal density)) that are } \\
\text { nanoscale }\end{array}$ & $0 \cdot 1 \%$ & $0.4 \%$ & $0.9 \%$ \\
\hline
\end{tabular}

Figure 4. The relationship between nanoparticle number and nanoparticle volume/mass, showing that increasing the number of nanoparticles substantially has minimal impact on nanoparticle proportion by volume/mass

The current best practice is to measure nanoparticle exposure using a combination of mass- and particle-based methods. This should be supplemented by the use of scanning electron microscopy (SEM) or transmission electron microscopy to enable characterisation of any particles (e.g. what substance they are, whether they are bound together, what shape they are) (Bard et al., 2015; Methner et al., 2009b; Vaquero et al., 2015).

\section{Common nano-enabled construction materials}

A database of 156 nano-enabled construction products has been developed through a combination of academic and manufacturers' literature, interviews with stakeholders in construction, demolition and nanomaterial production $(n=55)$ and laboratory testing (Table 1).

The following section provides more details about these products. As discussed previously, it is difficult to identify with certainty products that are nano-enabled and/or the nanomaterials contained. Consequently, the criteria for including products in Table 1 are broad, and include claims made by manufacturers regarding nanomaterial use - for example, the term 'nano' in a product title or literature, information from academic reports and assumptions based on product properties.

\subsection{Coatings}

Nano-enabled coatings are widely available, both for the home improvement market and for professionals. In addition, products

\begin{tabular}{lcl} 
Type & Number & $\begin{array}{l}\text { Nanomaterials commonly used } \\
\text { (bracketed entries less common) }\end{array}$ \\
\hline Coatings & 70 & Silica, titanium, silver (CNTs) \\
Glass & 23 & Metal oxides \\
Concrete & 22 & Silica, titanium (CNTs) \\
Steel & 11 & Nanostructured \\
Insulation & 10 & Silica aerogels \\
Composites & 1 & (CNTs, nanoclays) \\
Other (roofs, floors) & 19 & Titanium, aluminium
\end{tabular}

Table 1. Nano-enabled construction products identified in the UK (updated version from Jones et al., 2015b)

such as floors, toilets and roofs can be purchased that have been pre-treated with nano-based coatings. Coatings are the dominant and most numerous nano-enabled products (Lippy and West, 2015; van Broekhuizen et al., 2011; West et al., 2016), accounting for over half the current and predicted spending on construction nanomaterials (Freedonia, 2007). However, actual use relative to non-nano products remains low, with estimates suggesting they account for no more than $1 \%$ of the coatings market in Europe (Hincapié et al., 2015). The nanomaterials commonly used in coatings include silica, titanium dioxide, silver and carbon.

Nanosilica is used in various forms to provide water repellancy, abrasion resistance and ultraviolet protection (Pagliaro et al., 
2009). Greßler et al. (2010) describe the lotus leaf effect, where a surface that appears smooth is in fact covered in tiny protrusions that prevent water drops from adhering to the surface (Greßler et al., 2010). Other nanosilica-based coatings have different modes of action. Figure 5 illustrates the high contact angle of water drops on a concrete surface that has been coated and is now superhydrophobic.

Titanium dioxide is used for its photocatalytic effects. In the presence of ultraviolet light, dirt and particles as well as pollutants such as nitrogen oxides are broken down into water, carbon dioxide and nitrates. At the same time, the hydrophilic effect of the coating enables water to spread over the surface and wash away any waste products (Greßler et al., 2010). Thus, surfaces become 'self-cleaning', and there is also potential for the reduction of airborne pollution (Chen and Poon, 2009; Shen et al., 2012).

Silver is added to coatings for its anti-microbial effects, and marketed particularly for use in health care and food preparation environments. It is the nanomaterial most often listed as the active constituent in commercial products (PEN, 2014) as well as being the nanomaterial most commonly reported or recognised by those working in construction (Arora et al., 2014; Hincapié et al., 2015).

Carbon nanomaterials can be used in coatings. One CNT-based coating has been identified that is marketed for its ability to reduce corrosion. It is expensive and likely to be used only in specialist applications. CNTs might also be used for their fire resistance and their ability to reduce fouling in marine environments, but it is difficult to find evidence of commercially available products of this nature. Other carbonbased nanomaterials are used more widely, such as carbon

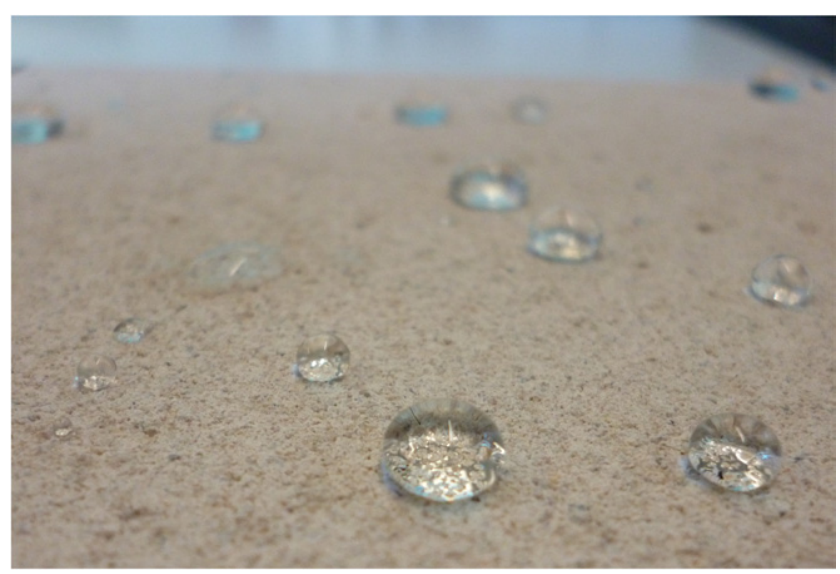

Figure 5. Water drops on a nano-coated concrete brick, showing how the drops form a near-spherical shape black, sold as a shield against radio waves. Graphene is reportedly also used, although, as the SEM of a coating product in Figure 6 illustrates, the particles are relatively large, around $40 \mathrm{~nm}$ thick, and several microns in the other two planes. They thus fall within the formal definition of ultra-thin graphite (Sanchez et al., 2011) rather than true graphene, which would typically be no more than 3 or $4 \mathrm{~nm}$ thick.

The lack of relevant information in safety data sheets makes it extremely difficult to identify the exact nanomaterial used in individual products. Table 2 provides some examples of nano-enabled coatings using information that is available publicly, although not always easy to find. Neither is information freely available on the proportions of nanomaterial used. For example, a review by Munafò et al. (2015) of titanium-based coatings used in stone conservation shows concentrations ranging from $0 \cdot 3$ to $10 \%$ (by weight) and also shows that products vary in their effectiveness in terms of self-cleaning, biocidal effects, anti-pollution effects and longevity. Other studies have shown variation in the effectiveness of coatings in preserving wood (Marzi, 2015) and the bactericidal effect of nanosilver (Molling et al., 2014). This lack of consistency is not limited to construction - nanosilver is added to socks to provide anti-odour and anti-microbial properties, but the quantities used have been shown to vary 700 fold between different brands (Benn and Westerhoff, 2008).

\subsection{Glass}

Nanomaterials can be applied to sheets of glass as part of the manufacturing process, and then used to construct window units with special properties. Multiple layers might be added to

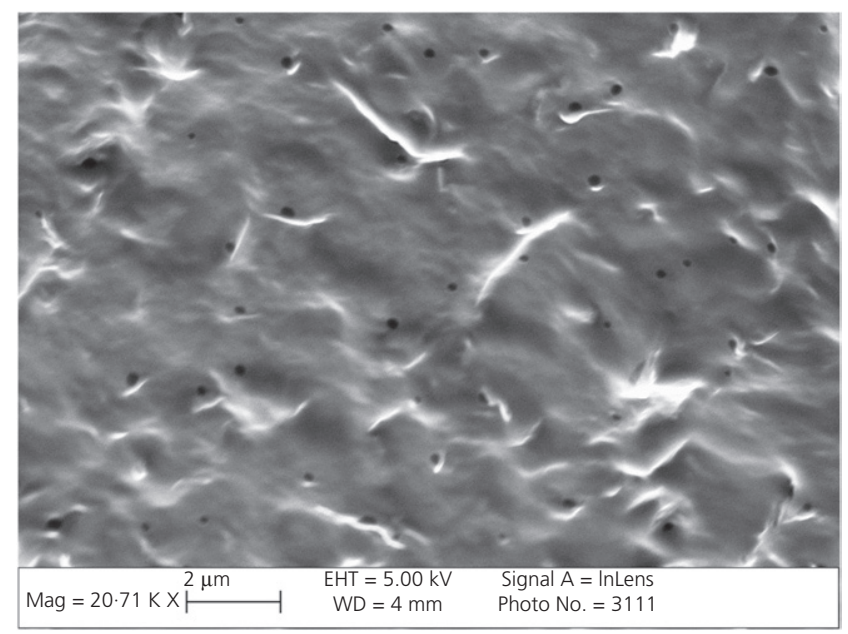

Figure 6. SEM image of a product marketed as 'graphene', but more accurately described as ultra-thin graphite or nanographite 


\begin{tabular}{|c|c|c|}
\hline Nanomaterial & $\begin{array}{l}\text { Properties attributable to } \\
\text { nanomaterial use }\end{array}$ & Availability and extent of application \\
\hline $\begin{array}{l}\text { Silica (silicon dioxide) } \\
\text { (including silane, } \\
\text { siloxane and } \\
\text { polysilazane; some } \\
\text { products refer to the } \\
\text { presence of } \\
\text { nanoparticles, others } \\
\text { state that they are } \\
\text { not particulate) }\end{array}$ & $\begin{array}{l}\text { Water repellancy } \\
\text { Easy cleaning, stay clean } \\
\text { Graffiti resistance } \\
\text { Hardening, protection } \\
\text { Scratch resistance }\end{array}$ & $\begin{array}{l}\text { Many products are available with these properties. Some are explicit } \\
\text { about being nano-enabled, although they may not be specific about } \\
\text { the substance used; these include 'Nanoclean cleaner' (Adseal), } \\
\text { 'ThermoSan' (Caparol), 'Surfapore' (Nanophos), 'Nansulate' } \\
\text { (Industrial Nanotech) and 'Nanostone and Nanowood' (Nanoprotect) } \\
\text { Other products have similar properties and are assumed to be } \\
\text { nano-enabled but their literature is less clear about this, including } \\
\text { 'Emcephob nanowax, Emcephob LE' (MC Bauchemie); 'Nanoshell' } \\
\text { (Nanoshell); 'Nanoguard' (Nanogate); 'Wondergliss' (Nanogate); } \\
\text { 'NewGuard; Nanopool; Lotusan' (Sto) }\end{array}$ \\
\hline Titanium dioxide & $\begin{array}{l}\text { Protective, anti-bacterial } \\
\text { Anti-pollution } \\
\text { Self-cleaning }\end{array}$ & $\begin{array}{l}\text { Many products are available with these properties and are explicit } \\
\text { about their nano-enablement - for example, 'FN coating' } \\
\text { (FN Nanoinc), 'KNOxOut' (Boysen), 'P and T-230' (nanoprotect) } \\
\text { and 'Surfashield' (nanophos) } \\
\text { Other products are available with similar properties, although they are } \\
\text { not marketed explicitly as being nano-enabled: 'NOxer' (Eurovia); } \\
\text { 'Climasan' (Sto) }\end{array}$ \\
\hline Silver & Anti-microbial & $\begin{array}{l}\text { Many products are available with these properties and are explicit } \\
\text { about their nano-enablement - for example, 'NPS 100, 200' } \\
\text { (Nanoprotect), 'Bioni roof, Bioni hygienic, Bioni nature' }\end{array}$ \\
\hline CNT & Resistance, anti-corrosion & $\begin{array}{l}\text { 'Teslan' (Tesla nano) is marketed as a coating that contains CNTs. } \\
\text { Other CNT products are marketed to be added to coatings but are } \\
\text { not necessarily available in commercially available coatings }\end{array}$ \\
\hline Other carbon & $\begin{array}{l}\text { Electromagnetic shielding } \\
\text { Anti-condensation } \\
\text { Heating paint }\end{array}$ & $\begin{array}{l}\text { Products likely to be based on carbon black are relatively cheap and } \\
\text { have been available for many years. They include 'Carbo e-therm', } \\
\text { 'Carboshield' (Future carbon) and 'Bloc paint' (Craig and Rose) } \\
\text { 'Graphenstone' is marketed as a product that contains graphene }\end{array}$ \\
\hline
\end{tabular}

Table 2. Nanomaterials in coatings

provide various properties within one unit, but the total coating layer remains very small, around $15 \mathrm{~nm}$ thick according to the manufacturer's literature (Pilkington, 2016).

Nanomaterials can provide windows with self-cleaning and thermal insulation properties (Table 3). They are also used to reduce solar gain in hot environments and can be used in switchable windows, where the amount of heat and light passing through a window can be controlled by the user.

\subsection{Concrete}

Concrete is widely discussed in academic literature as a nano-enabled material, with many papers describing the use of CNTs in a laboratory environment to improve the materials' strength, or to provide electrical conductivity (summarised, e.g. by Raki et al., 2010; Sanchez and Sobolev, 2010; Siddique and Mehta, 2014). CNTs can be added to concrete, but their commercial application is less advanced than might first appear from the literature (Table 4). CNTs are expensive, particularly when considering the quantities required for addition to mass concrete, even though typical recommended proportions are only $1 \mathrm{wt} \%$. They are also very difficult to disperse uniformly in concrete (Raki et al., 2010). Very few products appear close to commerciality, although one example has recently been approved for use by the Georgia Department of Transport in the USA (EE, 2015b).

More widely used in concrete is silica. Silica fume is an amorphous (non-crystalline) polymorph of silicon dioxide (silica). It is an ultrafine powder (with a typical average particle size of $150 \mathrm{~nm}$ ) collected as a by-product of silicon and ferrosilicon alloy production (Goodier et al., 2016, unpublished). It has been available as a nanoscale concrete additive for over 30 years (ACI, 1996) and might be used where enhanced durability, surface finish or early high strength is required. Nanosilica is an additional concrete additive, with a particle size around one tenth of that of silica fume (Sanchez and 


\begin{tabular}{|c|c|c|}
\hline Nanomaterial & $\begin{array}{l}\text { Properties attributable to } \\
\text { nanomaterial use }\end{array}$ & Availability and extent of application \\
\hline Titanium dioxide & Self-cleaning & $\begin{array}{l}\text { Windows with these properties are readily available from the main glass } \\
\text { suppliers - for example, 'Activ' (Pilkington) and 'Bioclean' (SGG). These are } \\
\text { often used on conservatories and glass roofs }\end{array}$ \\
\hline $\begin{array}{l}\text { Metal oxide coating } \\
\text { (probably silver) }\end{array}$ & $\begin{array}{l}\text { Thermal insulation (low } \\
\text { emissivity; low-e glass) }\end{array}$ & $\begin{array}{l}\text { Windows offering these properties are readily available from the main glass } \\
\text { suppliers - for example, 'Optitherm' (Pilkington), 'Planitherm' (SGG) and } \\
\text { 'Clima guard' (Guardian). They are used to ensure good insulation and aid } \\
\text { compliance with building regulations. Nanomaterials on windows are } \\
\text { referred to as 'soft' coatings; some window manufacturers favour older, } \\
\text { non-nano versions (known as 'hard' coatings) as these are more durable } \\
\text { (Jelle et al., 2012) }\end{array}$ \\
\hline Metal oxide coating & Solar control & $\begin{array}{l}\text { Windows with these properties are readily available from the main glass } \\
\text { suppliers - for example, 'Suncool' (Pilkington), 'Cool-lite' (SGG) and } \\
\text { 'Sunguard' (Guardian). These are used to reduce solar gain. They can be } \\
\text { used in conjunction with low-e coatings for internal climate control }\end{array}$ \\
\hline Silicon dioxide & Fire safety & $\begin{array}{l}\text { Products that contain an intumescent layer of precipitated nanosilica between } \\
\text { two panes of glass have been available for up to } 30 \text { years for use in } \\
\text { high-risk environments such as fire escape routes. Likely examples of } \\
\text { this include 'Pyrostop, Pyrodur' (Pilkington), 'Pyranova' (Schott) and } \\
\text { 'Pyroguard' (CGI) }\end{array}$ \\
\hline Tungsten dioxide & Smart switchable & $\begin{array}{l}\text { These allow the amount of light and heat passing through a window to be } \\
\text { varied by the user. They are relatively novel and expensive, and not widely } \\
\text { used outside of specialist projects. Examples of these include 'E-Control glas, } \\
\text { View glas and Sage glass' }\end{array}$ \\
\hline
\end{tabular}

Table 3. Nanomaterials in window glass

Sobolev, 2010), used to produce very high strength concretes. It is expensive and rarely used in commercial concreting operations.

Nanotitanium, described earlier for its photocatalytic effect in coatings, can also be used as a concrete additive, either throughout the concrete itself or applied as a separate coating layer (as it is only effective at the surface of the material where it can be exposed to light). White surfaces remain white as a result of this self-cleaning effect (Greßler and Gazsó, 2012), and there is some evidence of improved air quality through its use on pavements, tunnels and walls, provided suitable light is available (Allen et al., 2008; Guerrini, 2012; Shen et al., 2012). Although these products have been commercially available for many years (Zhu et al., 2004), there is limited evidence of their use in practice outside of showcase building projects and research studies.

\subsection{Steel}

The enhancement of steel comes from the use of nanotechnology rather than the addition of nanoparticles; processes are used that drive out impurities and refine grain boundaries to reduce corrosion or increase strength (Kolpakov et al., 2007; Shi, 2010). Changes can be made to the steel itself, or can be used for coatings that work in a similar way (Shi, 2010) (Table 5). Composites of nano-enabled steel and ceramics can be used to produce materials with high wear resistance and strength (Rodriguez-Suarez et al., 2012).

\section{5 (Aerogel) insulation}

Silica aerogels are a highly effective insulator (AA, 2014; Cuce et al., 2014) consisting of $97 \%$ air in a silica framework. Their nanoporous structure (manufacturers state that they do not contain nanoparticles) provides resistance to heat flow (Hanus and Harris, 2013). Aerogel-based products exist in three main forms (Table 6). They are much thinner and lighter than traditional materials for an equivalent level of thermal insulation and are therefore useful where there is limited space, for example, in retrofit and refurbishment projects. They are also used in challenging industries such as oil and gas. However, the products are expensive, typically 6-10 times the cost of more traditional insulation products (Cuce et al., 2014), and are therefore not frequently used in standard building projects. 


\begin{tabular}{|c|c|c|}
\hline Nanomaterial & Properties attributable to nanomaterial use & Availability and extent of application \\
\hline $\begin{array}{l}\text { Silica } \\
\text { Silica fume (particle size } \\
20 \mathrm{~nm}-1 \mu \mathrm{m} \text { average } \\
\text { approx } 150 \mathrm{~nm} \text { ) } \\
\text { Nanosilica (particle } \\
\text { size } 5-100 \mathrm{~nm} \text { ) } \\
\text { (Friede, } 2006 \text {; Sanchez } \\
\text { and Sobolev, 2010) }\end{array}$ & $\begin{array}{l}\text { Self-compacting, high strength, rapid } \\
\text { strength gain, enhanced pumping and } \\
\text { surface finish properties } \\
\text { Silica fume is used in ultra-high } \\
\text { performance concrete (also referred } \\
\text { to as reactive powdered concrete) }\end{array}$ & $\begin{array}{l}\text { Silica fume concrete has been in use for over } 30 \text { years } \\
\text { and is widely available from most major concrete } \\
\text { suppliers. Possible UK brands include 'Chronolia' } \\
\text { (Lafarge), 'Rapidcrete' (Breedon), 'Diamondcrete' } \\
\text { (Aggregate Industries) and 'Easyflow' (Hanson). } \\
\text { These are difficult to identify with certainty, } \\
\text { however, as they are not marketed as nanomaterials } \\
\text { by the manufacturers } \\
\text { Silica fume is moderately expensive and other } \\
\text { concrete additives can be used to achieve similar } \\
\text { properties. It is used in a relatively small proportion } \\
\text { of concrete projects } \\
\text { Nanosilica concrete is more expensive and it is } \\
\text { difficult to find examples of commercial applications }\end{array}$ \\
\hline Titanium & 'Self-cleaning' absorbs pollution & $\begin{array}{l}\text { This is available from several companies, examples } \\
\text { include 'TioCem' (Hanson) and 'Ti Active' } \\
\text { (Italcementi). Manufacturers generally specify that } \\
\text { the product contains nanotitanium } \\
\text { Although there are examples of this in the literature } \\
\text { in showcase or trial projects, it appears to be rarely } \\
\text { used in standard construction projects }\end{array}$ \\
\hline CNTs & $\begin{array}{l}\text { Increased strength and abrasion } \\
\text { resistance, reduced shrinkage } \\
\text { Electrically conductive }\end{array}$ & $\begin{array}{l}\text { This does not appear to be currently available as } \\
\text { a commercial product } \\
\text { A recent US trial on a road surface has been } \\
\text { conducted by Eden Energy, who are planning to } \\
\text { develop it commercially (EdenCrete) over the next } \\
2-4 \text { years (EE, 2015a, 2015b) }\end{array}$ \\
\hline
\end{tabular}

Table 4. Nanomaterials in concrete

\subsection{Other products}

Nanotechnology and nanomaterials are important in the development of photovoltaics, using smaller quantities of materials than traditional silica wafers. Some are available commercially, which use different forms of silica; others use nanoscale layers of materials such as cadmium, telluride, selenium and copper (Jelle et al., 2012; Khan and Arsalan, 2016; Pagliaro et al., 2008). In addition, solar cells based on other nanomaterials such as titanium, perovskite, quantum dots and graphene are at various stages of development and commercialisation.

Buildings may also contain other products that use nanotechnology, including radiator fluids based on metal nanoparticles (Alawi et al., 2014) (e.g. hydromx) and electronic devices such as batteries, organic light emitting diodes (oleds) and computer screens.

Nanoclays, which are either naturally occurring or synthetically created, consist of layers of silicate-based materials
(Morgan, 2007). They can be used in polymers to improve functionality in various ways, but there are no apparent construction products available commercially.

\section{The future of nanomaterials in construction - the risks and benefits}

This paper has presented an overview of the nanomaterials currently commercially available for use in construction. There are clearly benefits associated with the introduction of many nano-enabled products, but there may also be hazards, as health risks are associated with some nanomaterials. The exact form and the dose involved are important determinants of whether the risk is significant, making it important that there is a good understanding of the materials being used. However, reviewing the limited information available in the public domain has shown that it is difficult to be certain regarding the extent of nano-enablement in construction products and their market penetration. It is even more challenging to predict which new developments in nanomaterials may 


\begin{tabular}{|c|c|}
\hline Nanomaterial & nanomaterial use \\
\hline $\begin{array}{l}\text { Nanostructured } \\
\text { steel or steel } \\
\text { alloys }\end{array}$ & High strength, corrosion resistance \\
\hline $\begin{array}{l}\text { Ceramic metal } \\
\text { composite }\end{array}$ & $\begin{array}{l}\text { Hardness, repair of damaged metal } \\
\text { surfaces, high wear resistance, } \\
\text { corrosion resistance }\end{array}$ \\
\hline $\begin{array}{l}\text { Metallic } \\
\text { coatings }\end{array}$ & $\begin{array}{l}\text { High strength and toughness in } \\
\text { welding, high wear resistance }\end{array}$ \\
\hline
\end{tabular}

Availability and extent of application

A number of products are available, and have been marketed for at least 10-15 years. These include 'ChromX' (Mmfx), which is reportedly used in rebars for road construction and in other civil projects (Larsen, 2013)

Other products such as 'AHSS' and 'NSB' (Nanosteel) are marketed more for the automotive industry and for high-demand environments such as mining and oil and gas

Products such as 'Cermet' and 'PCompP' (Mesocoat) may be used in engines or motors used for construction, or in high-risk industries such as oil, gas and so on

Examples include 'SHS' (Nanosteel) and 'Santronic' (Sandvik). These are marketed, for example, for the coating of concrete chutes to prolong their life

Table 5. Nanomaterials in steel

\begin{tabular}{lll}
\hline Nanomaterial & Properties attributable to nanomaterial use & Availability and extent of application \\
\hline $\begin{array}{c}\text { Silica aerogel in } \\
\text { translucent particles }\end{array}$ & 'Lumira' particles (Cabot) are available on their & These products are readily available on the \\
& own or incorporated into wall/ceiling products \\
& such as 'Ecosky, Kalwall, Solera'. They allow light \\
transmission while still providing a high level of & market but their use is largely confined to \\
& thermal insulation
\end{tabular}

Silica aerogel in blanket These are available from several manufacturers: form some are specifically designed for protection against cold, others have high heat resistance; products include 'Pyrogel, cryogel, space loft' (Aspen aerogels), 'Thermal wrap' (Cabot) and 'Thermablok' (Acoustiblok)

Silica aerogel particles in Vacuum insulated panels are available for vacuum insulated installation in walls, flooring and roofs, products panels include 'Optim-R' (Kingspan) and 'Kevothermal'

Table 6. Nanomaterials in aerogel insulation materials

become commercially available for products in the near (or far) future and how widely they might be used.

Current evidence regarding the risk potential from nanoenabled construction products suggests that

current construction worker exposure to nanomaterials is likely to be relatively low (Larraza et al., 2015)

- the presence of existing hazards in coatings (such as solvents) is generally more significant than any specific risks from nanomaterials (Vaquero et al., 2015)

- the measures recommended to protect against existing risks in construction (e.g. water suppression, dust extraction at source, use of (face-fitted) FFP3 masks where appropriate (HSE, 2013a)) will in most cases be effective against the additional risks from nanomaterials (Boutry et al., 2015; Methner et al., 2009a).

However, it is important to be alert to the increased use of products that has been predicted (e.g. AECOM, 2014; Freedonia, 2007). This could involve: greater use of products that are already available, such as concretes based on amorphous silica or windows with self-cleaning or thermal coatings; an increased availability of products using potentially hazardous materials such as CNTs; or the introduction of products that use new materials with unknown toxicity profiles. The possible health implications of these scenarios are clearly diverse. 
Several surveys in Europe and the USA (Mann, 2006; Teizer et al., 2009; van Broekhuizen and van Broekhuizen, 2009; West et al., 2016) have shown that construction professionals often have limited knowledge of this field, which is not surprising given the many sources of uncertainty and lack of clarity discussed previously. It is nevertheless important that construction professionals ask searching questions of their suppliers when they are using new products. Where there is insufficient information available to judge the hazardousness of a material or product, it is recommended that a 'precautionary approach to risk management' is adopted (HSE, 2013b). This involves erring on the side of caution when assessing risk, particularly considering the possible consequences of an event even if the likelihood is low. For example, if a product contains CNTs but there is insufficient evidence to determine their shape, size and toxicity, it might be reasonable to assess risk as if they are a hazardous form, unless evidence is available to the contrary.

A high awareness of the new products being developed will also enable the construction industry to take full advantage of the benefits that nanotechnology can offer. With better understanding, there might be an increase in the use of products that are already available but rarely specified - for example, insulation that is four times as effective as traditional materials, photocatalytic concretes that could reduce airborne pollution or high-performance concrete that reduces the need for steel reinforcement. It might also encourage the early adoption of products that are on the horizon but not yet fully developed for example, vanadium-based coatings that eliminate the need for window cleaning on high-risk buildings, or photovoltaic cells that generate electricity from transparent windows.

Nanomaterials offer both benefits and risks. They are present in some commercially available construction products now, some of which are labelled and some of which are not, and there are undoubtedly more to come. It is important that the construction industry knows enough about them to make informed, smart and safe decisions.

\section{REFERENCES}

AA (Aspen Aerogels) (2014) http://www.aerogel.com/resources/ about-aerogel/ (accessed 26/11/2014).

ACl (American Concrete Institute) (1996) ACI Monograph 234R-96 'Guide for the Use of Silica Fume in Concrete'. ACI, Farmington Hills, MI, USA. See http://civilwares.free. fr/ACI/MCP04/234r_96.pdf (accessed 09/01/2015).

AECOM (2014) The Blue Book: Property and Construction Handbook International Edition. AECOM, Los Angeles, CA, USA. See http://www.aecom.com/content/wp-content/ uploads/sites/2/2015/10/Blue-Book-2014.pdf (accessed 26/11/2014).
Alawi OA, Sidik NAC, Mohammed H and Syahrullail S (2014) Fluid flow and heat transfer characteristics of nanofluids in heat pipes: a review. International Communications in Heat and Mass Transfer 56: 50-62.

Al-Jamal KT, Nunes A, Methven L et al. (2012) Degree of chemical functionalization of carbon nanotubes determines tissue distribution and excretion profile. Angewandte Chemie International Edition 51(26): 6389-6393.

Allen NS, Edge M, Verran J et al. (2008) Photocatalytic titania based surfaces: environmental benefits. Polymer Degradation and Stability 93(9): 1632-1646.

Arora SK, Foley RW, Youtie J, Shapira P and Wiek A (2014) Drivers of technology adoption - the case of nanomaterials in building construction. Technological Forecasting and Social Change 87: 232-244.

Azarmi F, Kumar P and Mulheron M (2014) The exposure to coarse, fine and ultrafine particle emissions from concrete mixing, drilling and cutting activities. Journal of Hazardous Materials 279: 268-279.

Azarmi F, Kumar P, Mulheron M et al. (2015) Physicochemical characteristics and occupational exposure to coarse, fine and ultrafine particles during building refurbishment activities. Journal of Nanoparticle Research 17(8): 1-19.

Bard D, Burdett G, Thorpe A, Cooke J and Sandys V (2015) Summary of Work Undertaken to Assess Workplace Exposure and Control Measures During the Manufacture and Handling of Engineered Nanomaterials. HSE, Sudbury, UK.

Baron MEA (2015) Safe Handling of Nano Materials and Other Advanced Materials at Workplaces. baua: Nanovalid, Dortmund, Germany. See http://www.nanosafetycluster.eu/ nanoToGo/Nano $\% 20$ to $\% 20$ go!/Brochure/Safe $\% 20$ handling $\% 20$ of $\% 20$ nanomaterials $\% 20$ and $\% 20$ other $\% 20$ advanced $\%$ 20materials\%20at\%20workplaces_v1-0.pdf (accessed 26/10/ 2015).

Benn TM and Westerhoff P (2008) Nanoparticle silver released into water from commercially available sock fabrics. Environmental Science and Technology 42(11): 4133-4139.

Boutry D, Damlencourt J, Ducros C et al. (2015) Best Practice Guide for Risk Protection in Relation with Manufactured Nanomaterials (mnms) in the Construction Sector Scaffold SPD13. Scaffold, Miñano, Spain. See http://scaffold.eu-vri. eu/filehandler.ashx?file=13834, SPD13 (accessed 28/07).

Boverhof DR and David RM (2010) Nanomaterial characterization: considerations and needs for hazard assessment and safety evaluation. Analytical and Bioanalytical Chemistry 396(3): 953-961.

BSI (2011) PAS 71: Vocabulary. Nanoparticles. BSI, London, UK. See http://shop.bsigroup.com/forms/Nano/PAS-71/ (accessed 04/06/2014).

Chen J and Poon C (2009) Photocatalytic construction and building materials: from fundamentals to applications. Building and Environment 44(9): 1899-1906. 
CLP (2009) Regulation No. 1272/2008: Classification, labelling and packaging of substances and mixtures, amending and repealing Directive 67/548/EEC and 1999/45/EC and amending Regulation (EC) No. 1907/2006. European Parliament and the Council, 16 December 2008.

Costa AL (2014) A Rational Approach for the Safe Design of Nanomaterials. Nanotoxicology: Progress Toward Nanomedicine. CRC Press, Boca Raton, FL, USA, pp. 37-44.

Cuce E, Cuce PM, Wood CJ and Riffat SB (2014) Toward aerogel based thermal superinsulation in buildings: a comprehensive review. Renewable and Sustainable Energy Reviews 34: 273-299.

David RM, Boverhof DR, Butala JH et al. (2013) Comparative Assessment of Nanomaterial Definitions and Considerations for Implementation. American Chemistry Council, Washington, DC, USA. See http://nanotechnology. americanchemistry.com/Nanotechnology/PanelActivities/Nanotechnology-Definitions/NanotechnologyPanel-Presents-at-Society-of-Toxicology.pdf (accessed 15/01/2015).

Deichmann W, Henschler D, Holmstedt B and Keil G (1986) What is there that is not poison? A study of the third defense by Paracelsus. Archives of Toxicology 58(4): 207-213.

Derbyshire D (2008) The Micro-Particles that Could Pose the Same Risk as Asbestos. Daily Mail, London, UK. See http://www.dailymail.co.uk/sciencetech/article1020802/The-micro-particles-pose-risk-asbestos. html\#ixzz3wZrexAFPedn (accessed 27/04/2016).

Donaldson K and Poland CA (2013) Nanotoxicity: challenging the myth of nano-specific toxicity. Current Opinion in Biotechnology 24(4): 724-734.

Donaldson K, Poland CA, Murphy FA et al. (2013) Pulmonary toxicity of carbon nanotubes and asbestos - similarities and differences. Advanced Drug Delivery Reviews 65(15): 2078-2086.

EC (European Commission) (2011) Commission Recommendation of XXX on the Definition of Nanomaterial. European Commission, Brussels, Belgium. See http://ec.europa.eu/ environment/chemicals/nanotech/pdf/commission recommendation.pdf (accessed 19/04/2016).

EC (2012) Commission Staff Working Paper Types and Uses of Nanomaterials, Including Safety Aspects. European Commission, Brussels, Belgium. See http://eur-lex.europa. eu/LexUriServ/LexUriServ.do?uri=SWD:2012:0288:FIN: EN:PDF (accessed 04/07/2014).

ECJRC (2014) Towards a Review of the EC Recommendation for a Definition of the Term 'Nanomaterial' Part 2: Assessment of Collected Information Concerning the Experience with the Definition. European Commission Joint Research Centre Institute for Reference Materials and Measurements, Brussels, Belgium, Report EUR 26744 EN.
See https://ec.europa.eu/jrc/en/publication/eur-scientificand-technical-research-reports/towards-review-ecrecommendation-definition-term-nanomaterial-part-2assessment-collected (accessed 16/02/2015).

EE (Eden Energy) (2015a) Annual Report for the Year Ended 30 June 2015. Eden Energy Ltd, Perth, Australia.

See http://www.edenenergy.com.au/pdfs/ 4cc57b34ea753cfc3f84dc7b22b121cd.pdf (accessed 20/01/2016).

EE (2015b) Eden Receives Formal Approval from GDOT for Use of EdenCrete in GDOT 24 hour Accelerated Concrete Applications and Class B Concrete Applications. Eden Energy Ltd, Perth, Australia. See http://www.edenenergy.com.au/ pdfs/ed2a1441b4346db25da7b83fc8012bb5.pdf (accessed 20/01/2016).

Freedonia (2007) Nanotechnology in Construction, US Industry Study with Forecasts for 2011, 2016 and 2025. Freedonia, Cleveland, OH, USA.

Friede B (2006) Microsilica-characterization of an unique additive. Proceedings of the 10th International InorganicBonded Fiber Composites Conference (IIBCC 2006), Sao Paulo, Brazil. Universidade de Sao Paulo and University of Idaho, Sau Paulo, Brazil, p. 135.

Froggett SJ, Clancy SF, Boverhof DR and Canady RA (2014) A review and perspective of existing research on the release of nanomaterials from solid nanocomposites. Particle and Fibre Toxicology 11(1): 17.

Giraldo MA (2008) Butterfly Wing Scales: Pigmentation and Structural Properties. University of Groningen, the Netherlands.

Greßler S and Gazsó A (2012) Nano Trust Dossier No. 032en Nano in the Construction Industry. Institute of Technology Assessment of the Austrian Academy of Sciences, Vienna, Austria. See http://epub.oeaw.ac.at/ita/nanotrust-dossiers/ dossier032en.pdf (accessed 19/04/2016).

Greßler S, Fiedeler U, Simkó M, Gazsó A and Nentwich M (2010) December-Last Update, Nano Trust Dossiers No. 020en Self-Cleaning, Dirt and Water-Repellent Coatings on the Basis of Nanotechnology. Institute of Technology Assessment of the Austrian Academy of Sciences, Vienna, Austria. See http://epub.oeaw.ac.at/0xclaa500d_ $0 \times 0024$ fa56.pdf (accessed 25/04/2014).

Grosse Y, Loomis D, Guyton KZ et al. (2014) Carcinogenicity of fluoro-edenite, silicon carbide fibres and whiskers, and carbon nanotubes. The Lancet Oncology 15(13): 1427-1428.

Guerrini GL (2012) Photocatalytic performances in a city tunnel in Rome: NOx monitoring results. Construction and Building Materials 27(1): 165-175.

Hansen SF, Jensen KA and Baun A (2014) NanoRiskCat: a conceptual tool for categorization and communication of exposure potentials and hazards of nanomaterials in consumer products. Journal of Nanoparticle Research 16(1): $1-25$. 
Hanus MJ and Harris AT (2013) Nanotechnology innovations for the construction industry. Progress in Materials Science 58(7): 1056-1102.

Hincapié I, Caballero-Guzman A, Hiltbrunner D and Nowack B (2015) Use of engineered nanomaterials in the construction industry with specific emphasis on paints and their flows in construction and demolition waste in Switzerland. Waste Management 43: 398-406.

HSE (Health and Safety Executive) (2013a) Construction Dust Construction Information Sheet No 36 (Revision 2). Health and Safety Executive, Sudbury, UK.

HSE (2013b) Using Nanomaterials at Work. Health and Safety Executive, Sudbury, UK.

IARC (International Agency for Research on Cancer) (2010) IARC Monographs on the Evaluation of Carcinogenic Risks to Humans Volume 93 Carbon Black, Titanium Dioxide, and Talc. IARC Working Group on the Evaluation of Carcinogenic Risks to Humans, Lyon, France. See http:/l monographs.iarc.fr/ENG/Monographs/vo193/mono93.pdf (accessed 08/01/2015).

lijima S (1991) Helical microtubules of graphitic carbon. Nature 354(6348): 56-58.

Jelle BP, Hynd A, Gustavsen A et al. (2012) Fenestration of today and tomorrow: a state-of-the-art review and future research opportunities. Solar Energy Materials and Solar Cells 96: $1-28$.

Jones W, Gibb A, Goodier C and Bust P (2015a) Managing the unknown - the health risks of nanomaterials in the built environment. In Proceedings of the 31st Annual ARCOM Conference, Lincoln, UK (Raiden A and Aboagye-Nimo E (eds)). Association of Researchers in Construction Management.

Jones W, Gibb A, Goodier C et al. (2015b) Nanomaterials in construction and demolition - how can we assess the risk if we don't know where they are? Journal of Physics: Conference Series 617(1): 12031.

Keller AA, McFerran S, Lazareva A and Suh S (2013) Global life cycle releases of engineered nanomaterials. Journal of Nanoparticle Research 15(6): 1-17.

Khan J and Arsalan MH (2016) Solar power technologies for sustainable electricity generation - a review. Renewable and Sustainable Energy Reviews 55: 414-425.

Kolpakov S, Parshin V and Chekhovoi A (2007) Nanotechnology in the metallurgy of steel. Steel in Translation 37(8): 716-721.

Krug HF (2014) Nanosafety research - are we on the right track? Angewandte Chemie International Edition 53(46): 12304-12329.

Kuhlbusch T, Asbach C, Fissan H, Göhler D and Stintz M (2011) Nanoparticle exposure at nanotechnology workplaces: a review. Particle and Fibre Toxicology 8(1): 22.

Kumar P and Morawska L (2014) Recycling concrete: an undiscovered source of ultrafine particles. Atmospheric Environment 90: 51-58.
Larraza Í, Pina R, López de Ipiña Peña J et al. (2015) Best Practice Guide for Risk Prevention in Relation with Manufactured Nanomaterials (mnms) in the Construction Sector SPD4. Scaffold, Miñano, Spain. See http://scaffold. eu-vri.eu/filehandler.ashx?file=13829 (accessed 28/07/2015).

Larsen KR (2013) Corrosion-resistant rebar extends service life of concrete bridge structures. Materials Performance 52(6): $17-22$.

Lee JH, Kuk WK, Kwon M et al. (2012) Evaluation of information in nanomaterial safety data sheets and development of international standard for guidance on preparation of nanomaterial safety data sheets. Nanotoxicology 7(3): 338-345.

Lippy BW and West G (2015) Identifying, assessing and controlling nanoparticle exposures among US construction workers. In Senn 2015 International Congress on Safety of Engineered Nanoparticles and Nanotechonologies (Pylkkänen L, Nyholm M and Drakvik E (eds)). Finnish Institute of Occupational Health, Helsinki, Finland, p. 38.

Mann S (2006) Nanotechnology and Construction. Nanoforum. See http://nanotech.law.asu.edu/Documents/2009/10/ Nanotech $\% 20$ and $\% 20$ Construction $\% 20$ Nanoforum $\%$ 20report_259_9089.pdf (accessed 17/04/2014).

Marzi T (2015) Nanostructured materials for protection and reinforcement of timber structures: a review and future challenges. Construction and Building Materials 97: 119-130.

Methner M, Hodson L, Dames A and Geraci C (2009a) Nanoparticle emission assessment technique (NEAT) for the identification and measurement of potential inhalation exposure to engineered nanomaterials - part B: results from 12 field studies. Journal of Occupational and Environmental Hygiene 7(3): 163-176.

Methner M, Hodson L and Geraci C (2009b) Nanoparticle emission assessment technique (NEAT) for the identification and measurement of potential inhalation exposure to engineered nanomaterials - part A. Journal of Occupational and Environmental Hygiene 7(3): 127-132.

Molling JW, Seezink JW, Teunissen BE, Muijrers-Chen I and Borm PJ (2014) Comparative performance of a panel of commercially available antimicrobial nanocoatings in Europe. Nanotechnology, Science and Aplications 7: 97-104.

Morgan AB (2007) Polymer-clay nanocomposites: design and application of multi-functional materials. In Material Matters Advanced Applications of Engineered Nanomaterials (Koltover I (ed.)). Aldrich Chemical Co., Inc., Milwaukee, WI, USA, vol. 2, p. 20.

Munafò P, Goffredo GB and Quagliarini E (2015) $\mathrm{TiO}_{2}$-based nanocoatings for preserving architectural stone surfaces: an overview. Construction and Building Materials 84: 201-218.

Novoselov KS, Geim AK, Morozov SV et al. (2004) Electric field effect in atomically thin carbon films. Science 306(5696): 666-669. 
Oberdörster G, Stone V and Donaldson K (2007) Toxicology of nanoparticles: a historical perspective. Nanotoxicology 1(1): $2-25$.

Orfescu C (2014) NanoArt: nanotechnology and art. In Nanotechnology: Concepts, Methodologies, Tools, and Applications (Khosrow-Pour M (ed.)). Information Resources Management Association, IGI Global, Hershey, PA, USA, p. 1008.

Pagliaro M, Ciriminna R and Palmisano G (2008) Flexible solar cells. ChemSusChem 1(11): 880-891.

Pagliaro M, Ciriminna R and Palmisano G (2009) Silica-based hybrid coatings. Journal of Materials Chemistry 19(20): 3116-3126.

PEN (Project on Emerging Nanotechnologies) (2014) Consumer Product Inventory. PEN, Washington, DC, USA. See http:// www.nanotechproject.org/cpi/ (accessed 26/11/2014).

Pilkington (2016) Pilkington Self-Cleaning Glass: Technical FAQs is Pilkington Activ ${ }^{T M}$ nanotechnology?. Nippon Sheet Glass Co., Ltd, Tokyo, Japan. See http://www.pilkington. com/en-gb/uk/householders/types-of-glass/self-cleaningglass/faqs/technical-faqs (accessed 20/01/2016).

Raki L, Beaudoin J, Alizadeh R, Makar J and Sato T (2010) Cement and concrete nanoscience and nanotechnology. Materials 3: 918-942.

Rauscher H and Roebben G (2015) Towards a Review of the EC Recommendation for a Definition of the Term 'Nanomaterial' Part 3: Scientific-Technical Evaluation of Options to Clarify the Definition and to Facilitate its Implementation. European Commission, Joint Research Centre, Brussels, Belgium.

Rodriguez-Suarez T, Bartolomé J and Moya J (2012) Mechanical and tribological properties of ceramic/metal composites: a review of phenomena spanning from the nanometer to the micrometer length scale. Journal of the European Ceramic Society 32(15): 3887-3898.

Sanchez F and Sobolev K (2010) Nanotechnology in concrete a review. Construction and Building Materials 24(11): 2060-2071.

Sanchez VC, Jachak A, Hurt RH and Kane AB (2011) Biological interactions of graphene-family nanomaterials: an interdisciplinary review. Chemical Research in Toxicology 25(1): 15-34.

Savolainen K, Pylkkänen L, Norppa H et al. (2010) Nanotechnologies, engineered nanomaterials and occupational health and safety - a review. Safety Science 48(8): 957-963.

Schilling K, Bradford B, Castelli D et al. (2010) Human safety review of 'nano' titanium dioxide and zinc oxide. Photochemical and Photobiological Sciences 9(4): 495-509.

Shen S, Burton M, Jobson B and Haselbach L (2012) Pervious concrete with titanium dioxide as a photocatalyst compound for a greener urban road environment. Construction and Building Materials 35: 874-883.
Shi X (2010) On the use of nanotechnology to manage steel corrosion. Recent Patents on Engineering 4(1): 44-50.

Siddique R and Mehta A (2014) Effect of carbon nanotubes on properties of cement mortars. Construction and Building Materials 50: 116-129.

Teizer J, Teizer W, Venugopal M and Sandha B (2009) Nanotechnology and Its Impact on Construction CII Report 251-11. Construction Industry Institute, Austin, TX, USA. van Broekhuizen F and van Broekhuizen P (2009) NanoProducts in the European Construction Industry State of the Art. European Federation of Building and Wood Workers, Amsterdam, the Netherlands.

van Broekhuizen P, van Broekhuizen F, Cornelissen R and Reijnders $L$ (2011) Use of nanomaterials in the European construction industry and some occupational health aspects thereof. Journal of Nanoparticle Research 13(2): 447-462.

van Broekhuizen $\mathrm{P}$, van Broekhuizen F, Cornelissen $\mathrm{R}$ and Reijnders L (2012) Workplace exposure to nanoparticles and the application of provisional nanoreference values in times of uncertain risks. Journal of Nanoparticle Research 14(4): 1-25.

Vaquero $C$, Jópez de Ipiña J, Stockmann-Juvala $\mathrm{H}$ and Vaananen V (2015) April 30-Last Update, Best Practice Guide for Risk Assessment of Manufactured Nanomaterials (MNMs) in the Construction Sector SPD9. Scaffold, Miñano, Spain. See http://scaffold.eu-vri.eu/filehandler. ashx?file=13832 (accessed 28/07/2015).

West GH, Lippy BE, Cooper MR et al. (2016) Toward responsible development and effective risk management of nanoenabled products in the US construction industry. Journal of Nanoparticle Research 18(2): 1-27.

WHO (World Health Organization) (2012) Nanotechnology and Human Health: Scientific Evidence and Risk Governance Report of the WHO Expert Meeting 10-11 December 2012. WHO, Bonn, Germany.

Zhu W, Bartos P and Porro A (2004) Application of nanotechnology in construction. Materials and Structures 37(9): 649-658.

\section{WHAT DO YOU THINK?}

To discuss this paper, please email up to 500 words to the editor at journals@ice.org.uk. Your contribution will be forwarded to the author(s) for a reply and, if considered appropriate by the editorial panel, will be published as discussion in a future issue of the journal.

Proceedings journals rely entirely on contributions sent in by civil engineering professionals, academics and students. Papers should be 2000-5000 words long (briefing papers should be 1000-2000 words long), with adequate illustrations and references. You can submit your paper online via www.icevirtuallibrary.com/content/journals, where you will also find detailed author guidelines. 